\title{
Professor Beesly, Positivism and the International The Patriotism Question
}

\author{
Gregory Claeys
}

\section{Introduction}

After 1789 the need to define some form of higher loyalty, above "patriotism", was an obvious focal point for participants in the international movement for democracy and social reform. The "rights of man", later to emerge as the concept of human rights, initially provided one such nexus of identity, and was often loosely linked to concepts like "universal benevolence" and "humanity". In Britain, through the Owenites, Chartist groups like the Fraternal Democrats, and various international organisations, a number of strategies spanning various forms of cosmopolitanism and internationalism were mooted in the next half century. ${ }^{1}$ After 1848 the romantic nationalism of the Italian Guiseppe Mazzini and the Hungarian Lajos Kossuth would provide considerable competition for such efforts, as that of Garibaldi would do for a later generation. ${ }^{2}$ The International Association, founded in 1855, attacked "the selfishness of nationalities", and proclaimed its goal of creating "a society which, consisting of members of different nationalities, may represent the future equality of peoples, and may accustom the mind to the idea of fraternity". ${ }^{3}$ By 1864 , the year of the founding in London of the International Working Men's Association (IWMA), one othernow little-known option, provided by the Positivist philosophy of Auguste Comte (1798-1857), was on offer. In Britain Comte's ideas would assume a somewhat different trajectory from elsewhere, and their anti-imperial component from

1 For a review of this process, my "Reciprocal Dependence, Virtue and Progress: Some Sources of Early Socialist Cosmopolitanism and Internationalism in Britain, 1790-186o", in Frits van Holthoon and Marcel van der Linden, eds., Internationalism in the Labour Movement 1830-1940 (Leiden, 1988), pp. 235-258. On the international movements in Britain prior to 1864 see Christine Lattek. Revolutionary Refugees. German Socialism in Britain, 1840-1860 (London, 2006).

2 On Mazzini see, most recently, Marcella Pellegrino Sutcliffe. Victorian Radicals and Italian Democrats (Woodbridge, 2014), and more generally my "Mazzini, Kossuth and British Radicalism 1848-54", Journal of British Studies, 28 (1989), 225-261.

3 Arthur Lehning. From Buonarroti to Bakunin. Studies in International Socialism (Leiden, 1970), p. 259 .

(C) GREGORY CLAEYS, 2018 | DOI 10.1163/9789004335462_022 
the late 1850 on onwards would loom much larger than in France. ${ }^{4}$ This perspective, inter alia, was presented at the first speech given at the founding meeting of the IWMA on 28 September by the chair of the meeting, Edward Spencer Beesly. ${ }^{5}$

This chapter explores Beesly's outlook, and briefly contrasts it to Marx's much better known ideas about patriotism, nationalism and imperialism. ${ }^{6}$ This contrast indisputably remains an instructive one. The communist movement went on to adopt a variety of strategies vis-à-vis the nation, the family, ethnicity, religion and other forms of identity in its search for a more powerful communal ethos to pit against the individualist philosophies produced by capitalism. To most of these lesser forms of association it was often hostile, viewing them as undermining a primary loyalty to the communal, or to the movement as a whole, later often subordinated in turn to the Party and its leader. By contrast Comte's followers, now largely forgotten, sought not to transcend patriotism or the nation-state but to redefine both. Despite their opposition to empire, thus, the Positivists were not opposed to patriotism as such, only to its irrational attachment to unduly large and aggressive states.

\section{Beesly, Positivism and the International}

Edward Spencer Beesly (1831-1915) was one of a group of Wadham College, Oxford, acolytes of the leading British Positivist Richard Congreve (1818-99), a physician with great affection for the ancient Greek polis. Congreve's conversion to Comte's anti-imperialist perspectives in the mid 1850 s led this group towards the distinctively hostile position on the British empire which it would maintain through the early twentieth century. Beesly's own attraction to the group, besides its sympathy for trades unionism, was chiefly to its anti-militarist tendencies and outlook, which meshed nicely with Positivist principles. ${ }^{7}$ When Beesly opened the proceedings at St Martin's Hall, Long

4 See my Imperial Sceptics: British Critics of Empire 1850-1920 (Cambridge, 2010), pp. 47-123.

5 The chief contemporary account is George Howell. "The History of the International Association", The Nineteenth Century, 4 (July 1878), 19-39.

6 The problem of patriotism is not explored in Royden Harrison. Before the Socialists. Studies in Labour and Politics 1861-1881 (London, 1965), pp. 251-342. It is not discussed at length in Julius Braunthal. History of the International 1864-1914 (London, 1977), or in the other standard work, Henry Collins and Chimen Abramsky. Karl Marx and the British Labour Movement. Years of the First International (London, 1965).

7 Beesly wrote that most of those present "would have hesitated to accept the name of Socialist. ... They joined the International because they felt carried away by a warm fraternal 
Acre, on 28 September 1864, he was Professor of History at University College London. The friend of many working class leaders in this period, including George Odger, George Howell and Robert Applegarth, he had been involved for some years in promoting an independent working class party, and would suffer much calumny for defending such causes. ${ }^{8} \mathrm{On}$ that day he was a great deal better known as a public figure than Karl Marx, who was only invited to attend at the last moment by the builder Randal Cremer. ${ }^{9}$ Beesly himself later recorded meeting Marx only in 1867 or 1868, and only got to know him well in September $1870 .{ }^{10}$ Most of those present indeed were probably not even socialists, much less communists. The founding of the IWMA, as Royden Harrison argued long ago, thus clearly owed much more to Beesly than it did to Marx."1 In Britain, moreover, it is no exaggeration to suggest that Positivism's influence on the left was as great if not greater than Marx's up to World War I, and that some part of the peculiarity of British socialism was a result. George Odger thought the International embodied the Positivist synthesis of "Order and Progress". ${ }^{12}$ Comte's ideas, certainly, inspired Ernest Belfort Bax, William Morris and most of the Fabians, especially the Webbs. Beesly himself was particularly significant for one of the most important communist activists of the 1880s and 189os, H.M. Hyndman, ${ }^{13}$ as well as for the Labour Church movement from which the Independent Labour Party would later emerge. ${ }^{14}$ The Positivists' role in founding the International was acknowledged as early as 1883 in P.H. Bagenal's comment that "Comtism ... furnished the framework of an international alliance

feeling for their working-class comrades on the Continent, with whom they felt themselves more closely united than with the wealthy classes in their own country" (quoted in Julius Braunthal. History of the International 1 864-1914, p. 97.)

Howell was closer to the Positivist Henry Crompton, who found him reading Comte in the late 1870 (F.M. Leventhal. Respectable Radical. George Howell and Victorian Working Class Politics, London, 1971, pp. 197-198.).

Beesly was subsequently invited to join the General Council of the International (he declined). See Documents of the First International. The General Council of the First International 1864-1866 (Moscow, 1964), pp. 36, 45. There is no mention of his role here in Henry Collins. "The International and the British Labour Movement: Origin of the International in England", in La Première Internationale. L'Institution, L'Implantation. Le Rayonnement (Paris, 1968), 23-40.

10 Beesly Papers, Special Collections, University College London, box 1.

11 Royden Harrison. "E.S. Beesly and Karl Marx", International Review of Social History, 4 (1959), 31; Harrison. Before the Socialists, pp. 41, 70-71.

12 Royden Harrison. Before the Socialists, p. 325.

13 Beesly was present at the founding of Hyndman's Social Democratic Federation in 1881 (Positivist Review, Jan. 1894, 37).

14 See my Imperial Sceptics, pp. 124-234 for details. 
between workingmen, and the International Association is declared to be its logical conclusion."15 This statement may have resulted from the Positivists' infamous defence of the Paris Commune of 1871 , which to them (as to Marx) exemplified the possibility of small-scale federalist government. ${ }^{16}$

How far then did Beesly's approach to nationalism and patriotism differ from Marx's at this crucial juncture in September 1864? Beesly began his opening address by describing the origins of the meeting in another gathering on 28 April 1863 respecting Poland's struggle against Russia. ${ }^{17}$ The current occasion, he trusted, aimed "to create a co-operative and fraternal feeling between the working men of England and other countries." The sole report known of this speech continues:

He then entered at length into the necessity of a close alliance between France and England as necessary to secure and maintain the liberties of the world. He denounced the wrong doings of government in violating international rights, and the English government was as bad, if not worse, than many of the Continental Powers. England wrongfully held possession of Gibraltar from Spain, and her conduct in China, Japan, India and elsewhere was cowardly and unprincipled. (Hear.) He urged upon all present to divest themselves of those selfish feelings disguised under the name of patriotism, and to maintain only those principles which their consciences told them were right and just. He then contrasted the different modes by which Englishmen and Frenchmen endeavoured to work out the rights of labour, and concluded a most effective speech amidst loud cheering. ${ }^{18}$

Four issues stand out distinctively here: the idea of a European league to promote peace, inspired originally partly by Saint-Simon, in which Britain and France would play leading roles; the Positivists' opposition to empire; their principled renunciation of that form of "patriotism" which was increasingly linked to imperialism; and their willingness to promote British, French and other working class organisations of mutual assistance and in aid of these ends.

\footnotetext{
$15 \quad$ National Review, 2 (1883-4), 31-32.

16 See The English Defence of the Commune, ed. Royden Harrison (London, 1971).

17 Beesly was at this time at work on the essay which would appear as "England and the Sea", in International Policy. Essays on the Foreign Relations of England (London, 1866), the definitive Positivist statement on the subject.

18 The Bee-Hive Newspaper, no. 155 (1 October 1864), 1. While there are some lectures in the Beesly Papers, University College London, this talk does not seem to have survived.
} 
In all these areas there was considerable distance from the views of Marx. The latter ridiculed in particular the Positivists' wish to "moralise capitalism" along republican lines while retaining private property, with its overtly paternalistic overtones. (Engels rejected "Professor Beesly and his friends" as "not properly a working-class party. They advocate a compromise to make wages labour tolerable, to perpetuate it; they belong to a political sect who believe that France ought to rule the world." $)^{19}$ Like Thomas Carlyle, whose enthusiasm for Captains of Industry was unbounded, and whose "feudal socialism" had been lambasted in the Communist Manifesto, Comte envisaged "moralised" bankers and capitalists managing the new society. Like the British labour leader John Burns in the 188 os, who told the Positivists that moralising the capitalist was about as practicable as moralising the tiger or boa constrictor, Marx could not countenance such ideas. ${ }^{20}$ Confessing himself "entirely hostile" towards Comtism, he nonetheless praised Beesly as "the only Comtist, both in England and in France, who deals with historical turning points (CRISES) not as a sectarian but as an historian in the best sense of the word."21 Beesly in turn conceded that while property was social in origin and thus by implication in disposition, the means of making it so were necessarily the subject of much disagreement. Like Comte, however, he regarded the abolition of private property as wrongheaded. He also continued to insist, as it was expressed by a Positivist convert from communism in 1870 , that the Communists "went wrong in wishing to introduce social changes by political means, instead of trusting to moral means." ${ }^{22}$ Beesly thus applauded the "peaceable determination of duties" over "the stormy discussion of rights". Regarding "debates on the possession of wealth as a barren agitation", he thus sought "an intellectual and moral regeneration to be brought about by a vast system of freely-organised education". ${ }^{23}$ He thought the Positivists shared with Marx an "indignation against the individualist theories of the propertied classes and their anti-social conduct", adding that "We both believe that the working class suffer terrible wrongs at the hands of the middle class, and that the social question is more important than the political". ${ }^{24}$ But his aim was not to "set class against class", but rather

19 Quoted in The English Defence of the Commune, p. 43.

20 Quoted in Royden Harrison. "Professor Beesly and the Working Class Movement", Asa Briggs and John Saville, eds. Essays in Labour History (London, 1960), p. 210.

21 Marx-Engels Collected Works, vol. 44 (London, 1989), p. 150 (Marx to Beesly, 12 June 1871).

22 E.S. Beesly. “The International Working Men's Association”, Fortnightly Review, ns 8 (1870), $517-518$.

23 E.S. Beesly. “The International Working Men's Association”, Fortnightly Review, ns 8 (1870), 531.

The English Defence of the Commune, p. 16. 
to "smooth over their differences, and dwell upon their common, rather than their divergent, interests". ${ }^{25}$ To Marx of course this was mere "bourgeois" reformism. But to the Positivists it was the means of avoiding the revolutionary excesses of $1793^{-4}$ or worse. Instead the Positivists offered the working classes a scheme aiming at full employment, fair wages, education and social security, wedded to a humanist religion. Beesly himself, however, was not dogmatic about Comte's Humanist ceremonies, and refused to follow Congreve into their formalisation into a system of ritual worship.

My concentration here will be briefly on the two main issues outlined in Beesly's speech, anti-imperialism and patriotism. In mid-19th century Britain the "nation" was rapidly expanding to become an enormous empire, and what came to be called jingoism in the late 1870 os was one logical result. The British Positivists were the most outspoken critics of this process. More than any other group, and certainly more than Comte's French followers, they dared to urge the renunciation of existing possessions, like Gibraltar, and condemned new acquisitions. As agnostics they recognised that the religious argument favouring conquest and, effectively, forced conversion, had been and remained immensely important, notably in British India. As historians of religion they also recognised the development of worship from fetishism to polytheism and monotheism, and deduced from this the need to tolerate Islam and every other form of observance as necessary stages along the path while aiming at the eventual destination of the Religion of Humanity. And so they championed a theory of organic human development which, in striking anticipation of liberal principles in the later 2oth century, recognised the rights of indigenous and non-Christian peoples and smaller states to preserve their independence against external encroachment.

But the Positivists were even more ambitious than this. In an influential essay collection entitled International Policy (1866), which was being composed in 1864, they also urged, on the basis of Comte's teachings, devolving all empires and nations into city-states of no more than a few million inhabitants. This they thought was the largest number of people capable of feeling a sentiment of mutual affection which might be termed patriotism. This would be supplemented by a further mutual attachment to the Religion of Humanity, which would unite the western European nations under the leadership of France and Britain.

The sources of this strategy lay in Comte's theory of the ideal human group. Comte regarded the family as the basic unit of society and held its existing patriarchal composition to be sacred, to the dismay of his more feminist admirers 
like John Stuart Mill. (Beesly averred that "For my part, as a Positivist, I believe that property and the family are institutions bound up with civilisation, and that they will survive all attacks.") ${ }^{26}$ Comte's view of patriotism derived from a psychology of what might be called proximate attachment, where our sentiments have necessarily to be bound most intimately by persons and places closest to us. This meant that feelings were organised in a logically ascending series of steps from the family, the seat of "moral existence", upwards.

Yet this was to be balanced against the necessity for the unity of humanity. But the answer to the need for a higher loyalty was not to abolish the lower forms of affection and identification. Comte warned that the "sophists who attack the Family, with their usual inconsistency, forget that the institution of Country is open to the same charges as that of Family". So Comte also insisted that "the sense of nationality ... ought to be subordinate to larger feelings of international fraternity." Hence he aimed to "restore the spirit of ancient manners by bringing into full harmony the different kinds of Civism under common subordination to the Great Being", noting that "Under this system, the bond between citizens, like the love within the home, will foster of itself a true affection for society, without trenching on the Religious sense of harmony, for which these sentiments will form the final moral training." ${ }^{27}$ Here, as for Marx, the working classes had a key role to play. At present national prejudice was strongest "in the middle classes, a fact principally due to industrial competition". By contrast "the working class is more free than any other from international prejudices ... [because] working men feel how similar their wants and their conditions are in all countries, and this feeling checks their animosity." Nonetheless Comte also insisted that patriotism "in its true sense" would "ever be the most usual type of ... the true social feeling". Our instincts of sympathy, he thought, "require for their full energy that the objects of them be constantly brought into presence with us. Were there not active and daily fellowship in common labours, and this is possible only in the City, there could be no expansion of universal Love; for a close identity of Belief would not be sufficient to form it." Thus "the union between Citizens will always represent the most extensive group of those affections which appeal equally to every part of our existence". Positivism would thus "re-establish the normal limit of extension of which this feeling of Patriotism is capable in practice." At present "the enormous size of modern states" meant that Europeans were actually "less habitually under the influence of patriotism than our Roman or even our

\footnotetext{
26 The English Defence of the Commune, p. 80.

27 Auguste Comte. System of Positive Polity (1851; 4 vols, Eng. edn., London, 1875), vol. 2, p. 179; vol. 1, pp. 66, 304-305.
} 
feudal forefathers". But patriotism remained "indispensable to the complete development of the social instinct, which it alone can preserve alike from the narrowness of family feeling and the vagueness of philanthropy." This implied dividing Europe into seventy large city-states republics of one to three million people each, making "five hundred states for the whole earth", none larger than Belgium, Tuscany or Sardinia. ${ }^{28}$

All the world might thus eventually be remade on the same model of devolved federalism, glued together by the Religion of Humanity. Thus in 1871 what the Commune meant to the Positivists implied above all the principle "of substituting municipalised provinces for a centralised empire". This involved rejecting majoritarian democratic oppression in favour of minority rights, as well as renouncing a standing army. ${ }^{29}$ Local patriotism, then, was quite compatible with complete hostility to jingoism. Such language would be closer to that of Mazzini's followers in the IWMA than to Marx's, and Mazzini would go on to attack the "barren cosmopolitan idea" of "the abolition of the idea of country and nationality" which he thought the IWMA represented..$^{30}$ Just how far Positivism influenced the International more generally throughout this period is an interesting question, but one beyond the constraints of this essay.

\section{Marx and Nationality}

But what did Marx think? In the later 1840 s the earliest application of the newlyminted materialist conception of history led him to see increasingly universal economic competition as destructive of "the former national exclusiveness of separate nations". Large-scale industry had already created a class - the bourgeoisie - "in which all nations have the same interest and for which nationality is already dead."31 The same process could be expected to underpin proletarian internationalism. Regarding less developed nations, a clear civilisational

28 Auguste Comte. System of Positive Polity, vol. 1, pp. 302-305, vol. 3, pp. 268-269.

29 The English Defence of the Commune, p. 186 (Frederic Harrison). He continued: "Among the leading ideas of the Commune was certainly that of putting an end to the era of national contests, and of founding a state of society such that all Western Europe might gradually form one great country, made up of many independent communities" (p. 228). Joseph Mazzini. "The International", The Contemporary Review, 20 (1872), 169, 576. The Positivists did much to ensure a warm reception for him when he toured Britain in 1864.

31 Marx-Engels Collected Works, vol. 5, p. 73. Engels however wrote in 1845 that the bourgeoisie could not transcend nationality, and that the great mass of the proletariat were "essentially humanitarian" in outlook (Ibid, vol. 6, p. 6.) Elsewhere he contrasted the "cosmopolitan exploitation" of the free traders with "universal brotherhood" (Ibid., 464). 
bias was evident. Marx was thus not critical of imperialism as such. He praised some of the destructive aspects of British rule in India, for example, for acting as "the unconscious tool of history" in undermining the village community. Engels applauded the French conquest of Algeria for similar reasons. ${ }^{32}$ Marx also remained disdainful of the "historyless" small nations of Europe. His cosmopolitanism from the 1840 os onwards stressed the need to abolish nationality, the principle of which he thought would disappear when private property was superseded. Bakunin's later view was not much different, the "necessary and inevitable conclusion" of the IWMA being, in his view, the "abolition - from the political as well as from the social viewpoint" of "all territorial States, political Fatherlands, and Nations", and its replacement by "the establishment of the great international federation of all local and national productive groups". ${ }^{33}$ Yet the persistence of such groups implied loyalties whose accommodation to a devotion to the federation remained essentially unexplored.

Whether in Marx and Engels' case this meant that nationalities or merely national antagonisms would vanish is less clear. But while Marx and Engels would support the federalist principle exemplified by the Paris Commune, they did not endorse a general principle of local patriotism of the sort the Positivists championed from the outset. To the contrary, they renounced any "sentimental consideration" for small nations like the Czechs, who would remain reactionary until the "complete extirpation or loss of their national character" took place. In the late 1860 s and early 1870 s, with Fenianism and the possibility of Irish independence, as well as that of Poland, these assumptions shifted somewhat. Engels indeed wrote to Karl Kautsky that "two nations in Europe have not only the right but even the duty to be nationalistic before they become internationalistic: the Irish and the Poles. They are most internationalistic when they are genuinely nationalistic." ${ }^{34}$ And in 1888 Engels would write that once Czarism had been overthrown "Poland will come to life again; Little Russia [Ukraine] will be able to choose its political connections freely; the Romanians, Hungarians and Southern Slavs will be able to regulate their affairs and their border questions free from foreign interference". This seems to indicate a position much closer to both Comte and his followers and the romantic nationalism of Kossuth and Mazzini, and of course the upsurge of nationalist sentiment which followed decolonisation after 1945. It has been contended by Isaiah Berlin that Marx's underestimation of the force of nationalism would

32 See my Imperial Sceptics, pp. 131-141 for details.

33 Michel Bakunin. The Policy of the International (1869) (London, 1919), p. 4.

34 Quoted in Imperial Sceptics, p. 136. 
remain one of the greatest weaknesses of his system. ${ }^{35}$ But there were points at which Marx and Engels' sympathy for nationalism did come to the surface, even forefront, of their thought.

\section{Conclusion}

Beesly's strategy in 1864 was intended to promote a mutual toleration of national differences while balancing the need to move all humanity towards civilisation. Given Marx's disdain for backward and "historyless" peoples this made Positivism less prone to a "civilisational" bias than Marxism. It tended less towards a variation on socialist imperialism of the sort which would emerge in the years of the Second International, and which can be construed as the position John Hobson adopted in his famous Imperialism. A Study (1902). It also made the Positivists much more immediately sympathetic to movements like Fenianism. Many British Comtists had an Irish background (Beesly's mother was Irish). This particularly oppressed nation yearning to be free of Britain's yoke was thus a paradigm for their own peculiar revolutionism. Yet this was to be accomplished within a framework of both working class internationalist organisations, a kind of European patriotism, and the Religion of Humanity. But Comte rejected a supranational form of cosmopolitanism. He warned that "Were the spirit of Patriotism trained to aspire after grand nationalities, it would induce the coarser minds to attempt schemes of oppression, that they might everywhere realise a form of State centralisation and political bureaucracy far beyond the degree natural to free civic union." This would be avoided in part by ensuring that the principle "of separation between Government and Priesthood will naturally prevent these sources of disturbance, whenever the Positive Religion has obtained sufficient influence." He also feared that if in "complete insurrection against the rich, the poor in their turn wish to be supreme", an "oppressive dominion" would eventually end "all collective action."36

Beesly continued to reiterate Comte's views on the family and patriotism for the next fifty years, insisting even in 1900 that he thought the majority of socialists "love their families and love their country." ${ }^{37}$ Such themes were ever alive in the IWMA, with Bakunin, who joined in 1868, insisting a year later that members would have to subordinate their "personal and every your family interest ... to the highest interest of the association, namely the struggle of

35 Isaiah Berlin. Karl Marx. His Life and Environment (2nd edn, Oxford, 1948), p. 188.

36 Auguste Comte. System of Positive Polity vol. 4, p. 284, vol. 2, p. 265.

37 The Social-Democrat (Aug. 1900), 249. 
Labour against Capital." ${ }^{38}$ The Comtist outlook of course fell into nearly utter neglect by the early 20 th century. Its efforts to create a secular religion seemingly represented one of the more dismal failures of an Enlightenment project. If, however, we are accustomed to mocking this viewpoint, we might recall that Marxism too eventually assumed the form of a secular religion. Its distance from Comtism was smaller here than we usually imagine. The point we might reiterate today, however, is that it had been clear since the French Revolution that determining a "higher" locus of loyalty than the nation was going to be very problematic. Allegiance to the cause of cosmopolitan republicanism, as Beesly called it, or revolutionary democratic internationalism (as we might today term it) led Paine to aid Napoleon in his proposed invasion of Britain in $1804 .{ }^{39}$ Around 1900 Ernest Belfort Bax found himself at least theoretically in an identical situation, with potentially divided loyalties, torn between a revolutionary regime with progressive principles and his own nation, implacably hostile to patriotism, and even happy to allow foreign invaders to impose correct principles on Britain. He also insisted that the proper object of Social Democratic loyalty was "the International Social-Democratic Party, the party of the class conscious proletariat", not humanity, a theme which would echo down for another century. ${ }^{40}$ The revolutionary movement of the 2oth century ironically probably did more to promote nationalism than to undermine it. ${ }^{41}$ And yet regional fragmentation of a Scottish, Flemish, Catalan or other variety may yet verge more towards Comte's aims than Marx's. At any rate it cannot be said that we have reached a satisfactory resolution of this problem in the 21st century. Yet only higher unities can meet the challenge of concentrated corporate and financial capital, and higher unities must attract our loyalty to rise to the occasion of the present enduring financial and political crisis. As the European idea threatens to unravel once again it is worth reminding ourselves of the implications of failing to meet this challenge.

\footnotetext{
$38 \quad$ Michael Bakunin. The Policy of the International (1869) (London, 1919), p. 3.

39 Bee-Hive, 22 April 1861, 1.

40 The Social-Democrat (Sept. 1900), 274.

41 Eugene Lyons. Assignment in Utopia (London, 1937), p. 139: "It has been one of the curious functions of the revolution, in ironical disregard of internationalist dogmas, to stir national consciousness in Russia. The mere emphasis on the hostile capitalist encirclement has tended to mark off the frontiers of their country in the minds of millions."
} 